Arab Univ. J. Agric. Sci., Ain Shams Univ., Cairo, 13(2), 309-325, 2005

\title{
GENETIC PARAMETERS OF SOME AGRONOMIC TRAITS IN YELLOW MAIZE UNDER TWO PLANTING DATES
}

[19]

El Shouny ${ }^{1}$, K.A.; Olfat. H. El Bagoury ${ }^{1}$; K.I.M. Ibrahim ${ }^{1}$ and S.A. Al-Ahmad $^{1}$

\begin{abstract}
Six population's seeds of four yellow maize crosses were formed during 2001 and 2002 growing seasons. Their plants were evaluated during 2003 growing season under two planting dates $\left(14^{\text {th }}\right.$ May and $29^{\text {th }}$ June) for six agronomic traits at the Agric. Res. Stat. of Fac. of Agric., Ain Shams Univ., Shalakan, Kalubia Governorate, Egypt. The present work aimed to determine the genetic parameters and their interactions with planting dates for grain yield per plant, 100-kernel weight, number of kernels per row, ear length, ear diameter, and days to silking in the six populations $\left(\mathrm{P}_{1}, \mathrm{P}_{2}, \mathrm{~F}_{1}, \mathrm{~F}_{2}, \mathrm{BC}_{1}\right.$ and $\left.\mathrm{BC}_{2}\right)$. Mean values of the six populations for all studied traits in all crosses were higher under normal planting date than those under late one. Therefore, normal planting date seemed to be non-stress environment. The potence ratio for all traits in the four crosses exceeded $(+1)$ except days to silking where it was less (-1). The highest heterosis percentage relative to mid and better parent reached $192.06 \%$ and $152.01 \%$ in cross 1 for grain yield per plant under late planting date. Inbreeding depression values were not-significant in all studied traits except ear diameter and 100-kernel weight in crosses 1 and 3 as well as grain yield per plant in all crosses also, it was positive for most studied characters in the four crosses except days to silking trait. Dominance occupied the first rank, additive or dominance type of epistasis occupied the second or the third contributor to the genetic effects in order of importance according to cross with exception of days to silking, where additive and additive occupied the first and the second ranks. Narrow sense heritability was relatively high for yield attributes whereas it was low for grain yield per plant. Meantime, expected genetic advance was relatively moderate or low for all traits. Therefore, it could be suggested that selection for most studied traits in the subsequent generations will be relatively more effective than in the early generations.
\end{abstract}

Key words: Maize, Planting date, Potence ratio, Heterosis, Inbreeding depression, Heritability, Genetic advance and Gene action.

INTRODUCTION

Maize is one of Egypt's principal cereal crops. It is used as feed for livestock and poultry. In Egypt, it is planted successfully under irrigation from mid-April to mid-August, although most of the area is planted between mid May to mid June

1- Department of Agronomy, Faculty of Agriculture, Ain Shams University, Shoubra El-Kheima, Cairo, Egypt

(Received November 2, 2004)

(Accepted November 29, 2004) 
as optimum period for production, whereas yield of grain decreases after that date. In this respect, El-Hosary et al (1990a \& b) and Eraky et al (2003) reported that in most cases mean values of grain yield and its components were higher under normal planting date compared with those under late planting date. Testing the genetic materials under different environments is valuable to select the high yielding genotypes of maize. Both heterosis and inbreeding depression share a similar phenomenon, therefore its logic to predict that heterosis in the $F_{1}$ well be followed by an appreciable reduction in $F_{2}$ performance. Yassien (1999a and b) and Amer \& Mosa (2004) found that the highest heterosis values relative to mid and better parent were obtained for grain yield per plant compared to other traits. On the other hand, Yassien (1999a \& b) reported that inbreeding depression was positive and not significant in grain yield and its components while, Amer and Mosa (2004) reported that inbreeding depression was significant for grain yield and its components with exception of number of rows per ear.

Generation mean analysis (GMA) is important to determine the gene action controlling grain yield and its components to develop appropriate breeding procedures. Several models have been developed for analysis of generation means (Hayman 1958 and Vandeer Veen 1959). These models provide information about epistasis besides estimation of additive and dominance variances and their effects. Also, these models evaluate parents, these information's are very important for the breeder in making decisions for the allocation of resources and expected response to selection. Gonzalez and Dudley (1981) used $\mathrm{P}_{1}, \mathrm{P}_{2}, \mathrm{~F}_{1}$,
$\mathrm{F}_{2}, \mathrm{~F}_{3}, \mathrm{~F}_{4}, \mathrm{BC}_{1}$ and $\mathrm{BC}_{2}$ of $15 \mathrm{~F}_{1}$ crosses from six inbred lines to estimate genetic parameters in maize and mentioned that the dominance effects were the most important genetic effects controlling the expression of grain yield per plant, ear length and ear diameter. Also, they noted that dominance $\mathrm{X}$ dominance effects were consistently negative for all traits except grain yield, whereas dominance effects for yield were larger than additive ones. Johanson et al (1955) reported that heritability estimates along with genetic gain are usually more useful than the heritability values alone in predicting the resultant effect for selecting the best individuals. On the other hand, high heritability is not always associated with high genetic advance, but to make effective selection high heritability should be associated with high genetic gain. Barakat (2003) found that heritability values were $61.4 \%$ for grain yield per plant and $63.2 \%$ for days to silking. The expected genetic advance was 7.97 and 11.18 for the same traits. The main objectives of the present study were to determine the optimum planting date for evaluation and suitable planting date for selection of the studied traits. Also, to determine the potence ratio, heterosis and inbreeding depression as well as types of gene action, heritability and predicted genetic advance for all studied traits.

\section{MATERIAL AND METHODS}

Six inbred lines of yellow maize were used in this study. Three of them namely; CML.326 ( $\left.\mathrm{P}_{1}\right), \quad$ CML.325 $\left(\mathrm{P}_{2}\right)$ and CML.134 $\left(\mathrm{P}_{3}\right)$ were introduced from CIMMYT. The remaining three inbred lines, viz. CM.202 ( $\left.\mathrm{P}_{4}\right)$, Roh.43Ht,B $\left(\mathrm{P}_{5}\right)$ and BS-10-8 $\left(\mathrm{P}_{6}\right)$ were kindly provided 
by the Maize Research Department, Field Crops Research Institute, Agricultural Research Center, Ministry of Agriculture and Land Reclamation, Giza, Egypt. The six parental lines were crossed in a half diallel fashion in 2001 season. In 2002 season, parents and the $F_{1}$ 's seeds were planted and at flowering time some of the $\mathrm{F}_{1}$ plants were selfed and others crossed to their parents to obtain $\mathrm{F}_{2}, \mathrm{BC}_{1}$ and $\mathrm{BC}_{2}$ seed. On the basis of the results from previous diallel trail in 2002 season the four crosses, i.e., CML.134 X BS-10-8 (cross 1), CM.202 X Roh.43Ht,B (cross 2), CML.326 X CML.325 (cross 3) and CML.326 X BS-10-8 (cross 4), which showed good yield and other agronomic characteristics, were selected for Generation mean analysis (GMA) study. The six populations i.e. $\mathrm{P}_{1}, \mathrm{P}_{2}, \mathrm{~F}_{1}, \mathrm{~F}_{2}, \mathrm{BC}_{1}$ and $\mathrm{BC}_{2}$ of each of the four crosses were grown in separate experiments under the two planting dates $\left(14^{\text {th }}\right.$ May and $29^{\text {th }}$ June). Each experiment was arranged in a Randomized Complete Block Design with four replicates. Each replication consisted of 13 ridges of $\mathrm{F}_{2}$ plants, 7 ridges for both $\mathrm{BC}_{1}$ and $\mathrm{BC}_{2}$ and 4 ridges for each of $\mathrm{P}_{1}, \mathrm{P}_{2}$ and $\mathrm{F}_{1}$ populations. Each ridge included 16 single plants, 25 $\mathrm{cm}$ apart within ridges of $70 \mathrm{~cm}$ width. All agricultural practices were applied as recommended. Data were recorded on 80 guarded plants for each of $\mathrm{P}_{1}, \mathrm{P}_{2}$ and $\mathrm{F}_{1}$ population, 484 plants for $F_{2}$ and 245 plants for each of $\mathrm{BC}_{1}$ and $\mathrm{BC}_{2}$ populations for grain yield per plant, 100-kernel weight, number of kernels/ row, ear diameter, ear length and days to silking. Data were statistically analyzed according to Snedecor and Cochran (1981). Differences were tested against the least significant difference at 0.05 and 0.01 levels of probability. The means and vari- ances were calculated for each population. The potence ratio was calculated as indicated by Smith (1952). Inbreeding depression and heterosis as the deviation of $\mathrm{F}_{1}$ generation from the mid-parent (MP) and better parent (BP) were calculated as described by Singh and Chaudhary (1977). Gene action was tested using the means of the six populations in each cross to estimate the six parameters for gene effects, using the equations illustrated by Hayman (1958) and Jinks and Jones (1958). The type of gene action; complementary or duplicate, was assessed based on the sign of $h$ and 1 gene effects i.e. complementary $(\mathrm{Com})=$. same sign and duplicate (Dupl.) = opposite signs. Broad (BSH) and narrow (NSH) sense heritabilities were estimated according to Burton (1951) and Warner (1952) for all studied characters. Genetic advance as percentage of $F_{2}$ mean $(\Delta \mathrm{G}$ $\%$ ) was estimated at $5 \%$ intensity of selection outlined by Allard (1960).

\section{RESULTS AND DISCUSSION}

Means and variances of the six populations for the studied characters in the four crosses are shown in Table (1). Significant differences between the two planting dates for all traits in the four crosses except cross 3 for days to silking and ear length, crosses 2, 3 and 4 for ear diameter, cross 1 for number of kernels per row and cross 3 for 100-kernel weight, indicating that these hybrids behaved somewhat differently from one planting date to another These results are in harmony with those obtained by ElHosary et al (1990 a and b); Eraky et al (2003) and Soliman et al (2004). Highly significant differences were shown 
Arab Univ. J. Agric. Sci., 13(2), 2005 
among the six populations in each cross for all traits, meaning that the populations within each cross were genetically different from each other for all characters. Population variance of $\mathrm{F}_{2}$ 's had the highest values for all studied traits in the four crosses. In general, results indicated that segregating generations $\left(\mathrm{BC}_{1}, \mathrm{BC}_{2}\right.$ and $\mathrm{F}_{2}$ ) had higher variances than the nonsegregating generations $\left(\mathrm{P}_{1}, \mathrm{P}_{2}\right.$ and $\left.\mathrm{F}_{1}\right)$ for all traits.

Our results are in harmony with those obtained by Awaad \& Hassan (1997); El-Hosary \& Abd El-Sattar (1998); Yassien (1999a \& b); Khalil (1999) and Amer \& Mosa (2004). The mean performance values of different populations for most studied traits at normal planting date being higher than the corresponding ones at the late one. This result is supported by those concluded by El Hosary et al (1990a) and Eraky et al (2003).

Estimates of potence ratio, heterotic effects and inbreeding depression for all traits are shown in Table (2). In most cases, the potence ratios for all traits in the four crosses exceeded (+1) except days to silking where it was less (-1) indicating that over dominance towards the earlier parent for silking while, it was towards the higher parent in the other traits. Similar results were found by El- Hosary \& Abd El-Sattar (1998) and Edwards \& Lamkey (2002). For all the studied characters in the four crosses heterosis values as deviation percentage of $F_{1}$ from the mid and better parents were positive except days to silking indicating that dominance and / or over dominance could be effective in the inheritance of most attributes. In most cases, heterotic effects were significant and highly significant relative to mid and better parent for most studied traits in the four crosses under the two planting dates. The highest heterosis percentage relative to mid and better parent under normal planting date reached $189.12 \%$ and $139.37 \%$ in cross 3 for grain yield per plant while the lowest ones reached $-15.57 \%$ in cross 2 and $12.72 \%$ in cross 4 for days to silking. On the other hand, the highest heterosis percentage relative to mid and better parent under late planting date reached $192.06 \%$ and $152.01 \%$ in cross 1 for grain yield per plant while the lowest ones reached $-18.27 \%$ and $-14.03 \%$ in cross 2 for days to silking. In this respect, Amer and Mosa (2004) found similar results considering to days to silking while, our estimates of heterosis percentage were higher than those obtained by Khalil (1999) and smaller than those obtained by Awaad and Hassan (1997). Inbreeding depression values were not-significant in most traits except ear diameter, 100-kernel weight and grain yield per plant and it was positive for most studied characters in the four crosses except days to silking trait. The positive inbreeding depression indicated that dominance played an important role for these traits and consequently manifestation of heterosis can not be maintained in the segregating generations. However, both heterosis and inbreeding depression are coincided to the same particular phenomenon therefore, it is logical to predict that heterosis in the $F_{1}$ well be followed by an appreciable reduction in $\mathrm{F}_{2}$ performance. Our results are in harmony with Awaad \& Hassan (1997); El-Hosary \& Abd ElSattar (1998); Khalil (1999); Yassien (1999 a \& b); Abd El-Aty \& Katta (2002) and Amer \& Mosa (2004).

Nature of gene action was computed according to Hayman (1958) and Jinks 
Arab Univ. J. Agric. Sci., 13(2), 2005 
\& Jones (1958) and the obtained values are presented in Tables (3, 4 and 5). The significance of any one of scales (A, B, C and D) is taken to indicate the presence of non-allelic interaction. The four crosses exhibited highly significant mean effects (m) for all traits under the two planting dates. Dominance occupied first rank in all characters with duplicate type of epistasis except days to silking in the four crosses under the two planting dates, indicating the possibility of obtaining transgressive segregates in later generations. Either additive (i) or dominance (1) type of epistasis was the second or the third contributor to the genetic effects according to cross. In this case selection had to be postponed to advanced generations for the realization of superior segregate. Similar findings were obtained by El- Hosary and Abd El-Sattar (1998); Khalil (1999); Yassien (1999a); Mosa (2003); Shafey et al (2003); El-Beially (2003) and Amer \& Mosa (2004). For days to silking, additive (i) and additive (d) occupied the first and the second ranks, respectively followed by dominance (1) type of epistasis with complementary type of epistasis suggesting a recurrent selection technique for improving this character in crosses 1,2 and 4 while additive (i) and dominance (l) gene interactions with duplicate type of epistasis were predominant in cross 3 under normal planting date, indicating the possibility of obtaining transgressive segregation in later generations for this cross. In this respect, most investigators (ElZeir et al 1993 and El-Beially, 2003) mentioned that the additive gene effects were found to be larger than dominance effects for days to silking. El-Rouby et al (1973) reported that the additive effects were predominant in the early planting date but dominance gene effects were important in the late one.

Heritability values in narrow sense (HNS) and expected genetic advance values as percentage of $F_{2}$ mean $(\Delta g \%)$ for all traits are shown in Table (6).

Heritability values in broad sense were higher than those of narrow sense for the studied characters in all crosses. In most cases narrow sense heritability values were relatively high or moderate for yield attributes and days to silking while the expected genetic advance values were relatively moderate or low for all traits. Therefore, it can be exploited efficiently through recurrent selection to make up all studied traits except days to silking where suggesting the importance of phenotypic selection for improving population mean based on, intensity of selection would be relatively moderate as well as progeny test of selected plants. Our data are supported by the results of El Rouby et al (1973), Awaad and Hassan (1997), Khalil (1999), Yassien (1999b) and Guzman and Lamkey (2000). Finally, from all the previous results it can be briefly concluded that:

The values of different genetic parameters under the study were higher at normal planting date than those at late one for all traits with exception of heritability in narrow sense for ear height, genetic advance percentage for plant height, potence ratio for each of ear length, ear height and days to silking and heterosis percentage for grain yield per plant, ear diameter and days to silking where their values were higher under late planting date compared with those under normal one.

On the other hand, no trend was observed for HNS for ear diameter and ear length, $\Delta \mathrm{G} \%$ for number of kernels per 
Arab Univ. J. Agric. Sci., 13(2), 2005 
Arab Univ. J. Agric. Sci., 13(2), 2005 
Table 6. Heritability estimates in broad and narrow sense (HBS \& HNS) and expected genetic advance $(\Delta G \%)$ for studied traits in the four yellow maize crosses under the two planting dates

\begin{tabular}{|c|c|c|c|c|c|c|c|c|}
\hline Crosses & $\begin{array}{c}\text { Genetic } \\
\text { parameters }\end{array}$ & $\begin{array}{l}\text { planting } \\
\text { date }\end{array}$ & $\begin{array}{l}\text { Days to } \\
\text { Silking }\end{array}$ & $\begin{array}{c}\text { Ear } \\
\text { length }\end{array}$ & $\begin{array}{c}\text { Ear } \\
\text { diameter }\end{array}$ & $\begin{array}{c}\text { No. of } \\
\text { kernels/ } \\
\text { row }\end{array}$ & $\begin{array}{c}\text { 100-kernel } \\
\text { weight }\end{array}$ & $\begin{array}{l}\text { grain } \\
\text { yield/ } \\
\text { plant }\end{array}$ \\
\hline \multirow{6}{*}{$\begin{array}{c}1 \\
\left(\mathrm{P}_{3} \mathrm{X} \mathrm{P}_{6}\right)\end{array}$} & HBS & $D_{1}$ & 87.00 & 76.69 & 83.00 & 76.09 & 93.04 & 88.18 \\
\hline & & $\mathrm{D}_{2}$ & 89.29 & 71.20 & 76.87 & 73.19 & 91.65 & 87.23 \\
\hline & HNS & $\mathrm{D}_{1}$ & 77.00 & 59.45 & 36.02 & 55.39 & 57.25 & 23.00 \\
\hline & & $\mathrm{D}_{2}$ & 53.07 & 62.49 & 60.29 & 27.32 & 43.41 & 20.38 \\
\hline & $(\Delta \mathrm{G} \%)$ & $D_{1}$ & 8.36 & 17.52 & 7.26 & 26.85 & 21.66 & 17.21 \\
\hline & & $\mathrm{D}_{2}$ & 6.67 & 17.59 & 12.71 & 14.09 & 20.15 & 14.26 \\
\hline \multirow{6}{*}{$\begin{array}{c}2 \\
\left(\mathrm{P}_{4} \mathrm{X} \mathrm{P}_{5}\right)\end{array}$} & HBS & $\mathrm{D}_{1}$ & 78.00 & 77.02 & 70.05 & 77.00 & 95.28 & 85.87 \\
\hline & & $\mathrm{D}_{2}$ & 87.14 & 59.94 & 65.05 & 73.59 & 77.26 & 85.57 \\
\hline & HNS & $\mathrm{D}_{1}$ & 62.00 & 51.78 & 30.43 & 20.30 & 57.00 & 37.00 \\
\hline & & $\mathrm{D}_{2}$ & 56.26 & 45.68 & 41.21 & 49.70 & 49.48 & 27.02 \\
\hline & $(\Delta \mathrm{G} \%)$ & $\mathrm{D}_{1}$ & 6.07 & 16.49 & 8.24 & 9.70 & 29.20 & 17.11 \\
\hline & & $\mathrm{D}_{2}$ & 8.11 & 13.22 & 9.49 & 26.38 & 16.09 & 21.83 \\
\hline \multirow{6}{*}{$\begin{array}{c}3 \\
\left(\mathrm{P}_{1} \mathrm{X} \mathrm{P}_{2}\right)\end{array}$} & HBS & $\mathrm{D}_{1}$ & 89.00 & 82.15 & 70.43 & 86.47 & 90.00 & 87.00 \\
\hline & & $\mathrm{D}_{2}$ & 84.49 & 77.86 & 62.13 & 70.23 & 73.92 & 67.04 \\
\hline & HNS & $\mathrm{D}_{1}$ & 63.00 & 43.00 & 48.59 & 51.49 & 53.00 & 33.00 \\
\hline & & $\mathrm{D}_{2}$ & 65.42 & 42.86 & 39.20 & 45.85 & 40.03 & 31.42 \\
\hline & $(\Delta \mathrm{G} \%)$ & $\mathrm{D}_{1}$ & 8.05 & 15.31 & 9.49 & 25.37 & 19.25 & 15.88 \\
\hline & & $\mathrm{D}_{2}$ & 8.80 & 15.19 & 6.60 & 22.79 & 15.36 & 17.66 \\
\hline \multirow{6}{*}{$\begin{array}{c}4 \\
\left(\mathrm{P}_{1} \mathrm{X} \mathrm{P}_{6}\right)\end{array}$} & HBS & $\mathrm{D}_{1}$ & 93.90 & 76.21 & 78.17 & 75.75 & 91.90 & 93.90 \\
\hline & & $\mathrm{D}_{2}$ & 81.21 & 61.42 & 65.63 & 59.50 & 69.41 & 82.98 \\
\hline & HNS & $\mathrm{D}_{1}$ & 77.00 & 42.00 & 60.00 & 34.00 & 51.00 & 19.00 \\
\hline & & $\mathrm{D}_{2}$ & 63.50 & 32.72 & 42.50 & 30.33 & 35.01 & 21.92 \\
\hline & $(\Delta \mathrm{G} \%)$ & $D_{1}$ & 9.04 & 12.66 & 11.48 & 15.31 & 19.73 & 16.74 \\
\hline & & $\mathrm{D}_{2}$ & 6.51 & 9.67 & 8.20 & 15.36 & 13.95 & 12.27 \\
\hline
\end{tabular}


row, ear diameter and days to silking. The normal planting date is considered as an optimum environment for evaluation all studied traits while the late planting date is more suitable environment for obtaining more variation for most traits. In most cases, selection would be effective in advanced generations for improving the most studied traits.

\section{REFERENCES}

Abd El-Aty, M.S. and Y.S. Katta (2002). Estimation of heterosis and combining ability for yield and other agronomic traits in maize hybrids (Zea mays L.). J. Agric. Sci., Mansoura Univ., 27 (8): 5137-5146.

Allard, R.W. (1960). Principles of Plant Breeding. pp. 20-51. John Wiley, New York.

Amer, E.A. and H.E. Mosa (2004). Gene effects of some plant and yield traits in four maize crosses. Minufiya $J$. Agric. Res. 1(29): 181-192.

Awaad, H.A. and E.E. Hassan (1997). Estimation of genetic parameters and their implication in maize breeding programs. Zagazig J. Agric. Res. 24 (1): 5162.

Barakat, A.A. (2003). Genetic variance, heritability and genetic gain from selection in a yellow maize population. Minufiya J. Agric. Res. 28 (1): 773-786.

Burton, G. W. (1951). Quantitative inheritance in pearl millet (Pennisetum glaucum). Agron. J. 43: 409 - 417.

Edwards, J.W. and K.R. Lamkey (2002). Quantitative genetics of inbreeding in a synthetic maize population. Crop Sci. 42: 1094 -1104.

El Beially, I.E. (2003). Genetic analysis of yield characters in yellow maize inbred lines. Zagazig J. Agric. Res. 30(3): 677689.

El Hosary, A.A. and A.A. Abd El Sattar (1998). Estimation of gene effects in maize breeding programs for some agronomic characters. Bull. Fac. Agric., Cairo Univ., 49:501-516.

El Hosary, A.A.; G.A. Sary and A.A. Abd El-Sattar (1990a). Studies on combining ability and heterosis in maize (Zea mays L.). I-Growth attributes. Egypt J. Agron. 15 (1-2): 23-34.

El Hosary, A.A.; G.A. Sary and A.A. Abd El-Sattar (1990b). Studies on combining ability and heterosis in maize (Zea mays L.). II- Yield and yield components. Egypt. J. Agron. 15 (1-2): 9-22.

El Rouby, M.M.; Y.S. Koraiem and A.A. Nawar (1973). Estimation of genetic variance and its components in maize under stress and non-stress environments. Egypt. J. Genet. Cytol., 2: 10-19.

El-Zeir, F.A.; M.A. Younis; F.M. Omer and A.A. Galal (1993). Estimation of genetic variability in a composite variety of maize using design-1 and $\mathrm{S}_{1}$ families. J. Agric. Res. Tanta Univ., 19(1): 114122.

Eraky, A.G.; A.R. Al-Kaddoussi; S.E. Sadek and M.M. Osman (2003). Evaluation of improving cycle-1 for $S_{1}$ lines and half-sib families of yellow maize under different environments. Zagazig $\mathbf{J}$. Agric. Res., 30(2): 359-383.

Gonzalez, J.M and J.W. Dudley (1981). Epistasis in related and unrelated maize hybrids determined by three methods. Crop Sci. 21: 644-651.

Guzman, P.S. and K.R. Lamkey (2000). Effective population size and genetic variability in the BSII maize population. Crop Sci. 40: 338-346.

Hayman, B.I. (1958). The separation of epistatic from additive and dominance 
variation in generation means. Heredity, 12: 371-390.

Jinks, J.L. and R.M. Jones (1958). Estimation of the components of heterosis. Genetics, 43: 223-234.

Johanson, H.W.; H.F. Robinson and R.E. Comstock (1955). Estimates of genetic and environmental variability in soybean. Agron. J. 47: 314-318.

Khalil, A. N. M. (1999). Genetic effects estimated from generation means in two maize crosses. Minufiya J. Agric. Res., 24(6): 1911-1924.

Mosa, H.E. (2003). Heterosis and combining ability in maize (Zea mays L.). Minufiya J. Agric. Res., 28 (5): 13751386.

Shafey, S.A.; H.E. Yassien; I.M.A. ElBeially and O.A.M. Gad-Alla (2003). Estimates of combining ability and heterosis effects for growth, earliness and yield in maize (Zea mays L.). J. Agric., Mansoura Univ., 28 (1): 55-67.

Singh, R.K. and B.D. Chaudhary (1977). Biometrical Method in Quantitative Genetic Analysis. pp.79-101. Kamla Nagar, New Delhi 110007. India.

Smith, H.H. (1952). Fixing Transgres sive Vigor in Nicotiana rustica. Heterosis, pp.25-43. Iowa State College Press, Ames, Iowa, U.S.A.

Snedecor, G.W. and W.G. Cochran (1981). Statistical Methods. pp. 175-191. $6^{\text {th }}$ (Edit), Iowa Stat. Univ. Press, Ames, Iowa, U.S.A.

Soliman, F.H.S.; A.I.N. Abd El-Aal; A.A. Mahmoud; A.A. Ahmed and M.A. Abd El-Moula (2004). Maize production in new lands at Toshka and east El Ewinat regions. Bull Fac. Agric. Cairo Univ., 55: 237-264.

Vandeer Veen, J.H. (1959). Test of non allelic interaction and linkage for quantitative characters in generation derived from two diploid pure lines. Genetica 30: 201. (Cited from El Hosary and Abd El Sattar 1998)

Warner, J.N. (1952). A method for estimating heritability. Agron. J. 44: 427430.

Yassien, H.E. (1999a). Genetic parameters for yield and its components in some maize crosses. Al-Azhar J. Agric. Res. 30: 1-15.

Yassien, H.E. (1999b). Genetic analysis in three yellow maize (Zea mays, L.) crosses. J. Agric. Mansoura Univ., 24 (10): 5331-1999. 
بحلة اتحاد الجامعات العربية للدراسات والبحوث الزراعية، جامعة عين شمس، القاهرة ، 13(2)، 309-325، 2005

الثوابت الوراثية لبعض الصفات المحصولية في الأرة الصفراء تحث ميعادين للزراعة

[19]

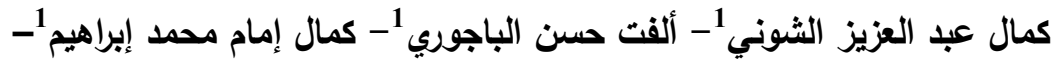

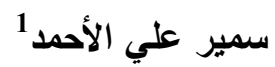

1- قسم المحاصيل - كلية الزراعة - جامعة عين شمس - شبرا الخيمة - القاهرة - مصر

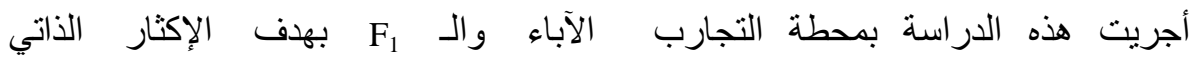

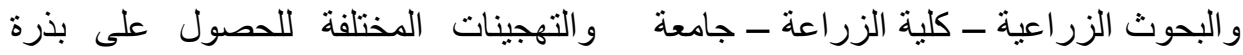
عين شمس - بثلقان - محافظة القليوبية الجيل الثاني خلال الموسم الصيفي لأعوام 2001، و و BC2 وكذلك المحافظة على بذور الجيل

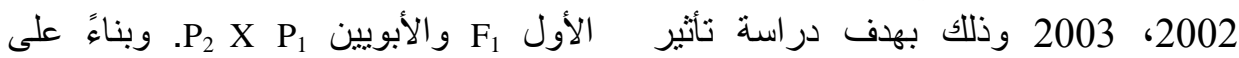
ميعادين للزراعة (العادي والمتأخر) على نتائج تحليل البيانات المتحصل عليها من بعض الصفات النباتية والمحصولية وعلى الهجن الفردية في موسم 2002 أمكن إنتخاب

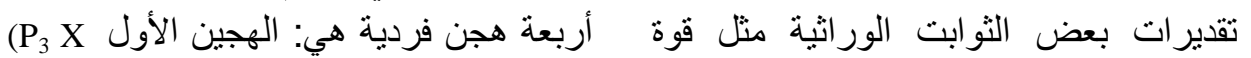

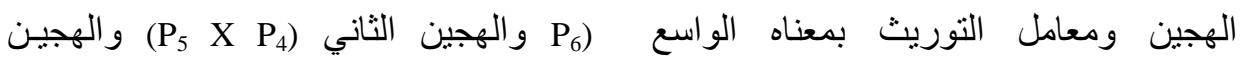

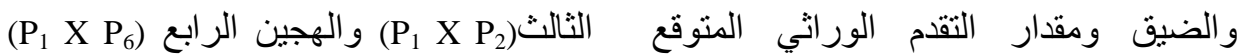
ودر اسة طبيعة الفعل الجيني وتعبيره وكذللك حيث زر عت حبوب العثائر الستة لكل هجين دليل أو درجة السيادة والنقص المتوقع نتيجة في الموسم 2003 تحت ميعاديين للزرة واعة التربية الداخلية. استخدمت في هذه الدراسة

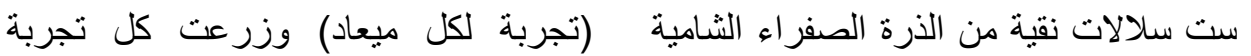

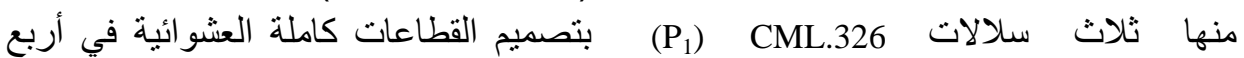

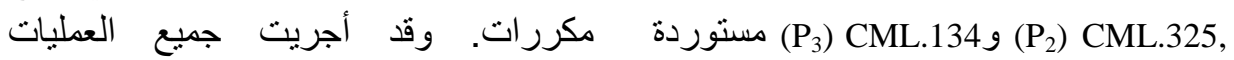

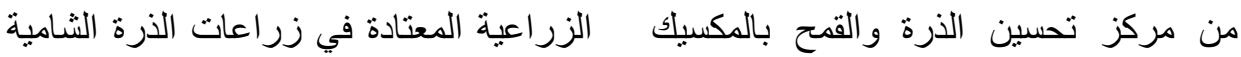

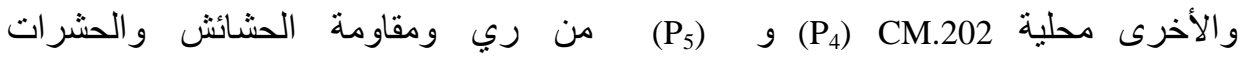
و Roh.43Ht,b تهجينات تبادلية بينها (في إتجاه واحد) في و القياسات على 80 نبات محاط لكل من موسم 2001 وفي موسم 2002 زرعت التراكيب الوراثية الأبوية والجيل الأول 
ملائمة للنمو الخضري لنباتات الذرة الثنامية. مانه. 3- كانت قيم قوة الهجين عالية المعنوية في كل الهجن تحت الدراسة في ميعادي الزراعة. وكانت أعلى هذه القيم بالنسبة

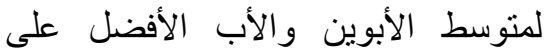
التوالي سالبة في ميعاد الزراعة العادي الادي الإني

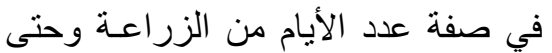
ظهور الحريرة بينما كانت موجبة في في التي

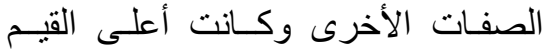
192.06\% و 152.01\% بالنسبة لصفة وحسة أنتاجيـة النبات من الحبوب في الهجين الأول تحت مبعاد الزر اعه المتأخر. 4- تخطت درجة السيادة +1 في كل الصفات تحت ميعادي الزراعه عدا صفة عدد الأيام من الزراعة حتى ظهور الحريرة

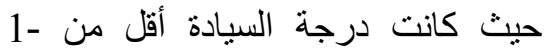
وهذا يشير إلى أن السيادة الفائقة تتجه التهادة نحو الأب المبكر في صفة التزهير بينما تتجه نحو الأب الأعلى في الصفات

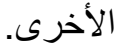
5- إن قوة الهجين و التدهور الناتج عن

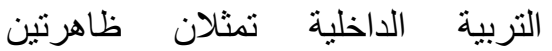
منلازمتين لذلك كان من المنطقي أن نلاحظ حدوث تدهور في الجيل الثاني إلاني

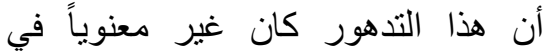
معظم الصفات عدا صفة إرتفاع النبات وقطر الكوز ووزن الـ 100 حبة و إنتاجية النبات من الحبوب كما كانت قيم التدهور موجبة قي كل الصفات عدا صفة عدد الأيام من الزر اعة وحتى ظهور الحريرة.
و245 نبات لكل من الجيلين الرجعيين و484 نبات من الجيل الثاني لصفات عدد الأيام من الزراعة حتى ظهور الحريرة (مباسم النورة المؤنثة)، طول الكوز بالسم، قطر الكوز بالسم، عدد الحبوب بالصف، وزن المائة حبة

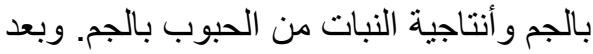
تحليل البيانات المتحصل عليها أحصائياً وور اثياُ لكل ميعاد زر اعي على حده.

\section{يمكن تلخيص النتائج المتحصل عليها على النحو الآتي}

1- أظهرت نتائج تحليل التباين أن هناك من مناك فروق معنوية بين متوسطات ميعادي

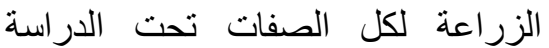

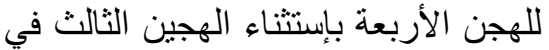
صفة عدد الأيام من الزر اعة حتى ظهور لإعر الحريرة وصفة طول الكوز وكذللك

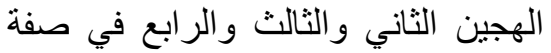
قطر الكوز والهجين الأول في صفة عدد الحبوب بالصف والهجين الثالث في في فئه صفة وزن الـ 100 حبة. 2- كانت القيم المعبرة عن سلوك العثائر

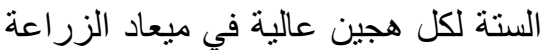
العادي مقارنة بتلك تحت ميعاد الزراعة

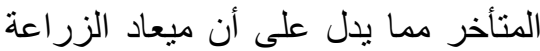
العادي يمثل بيئة مناسبة وغير مجهدة

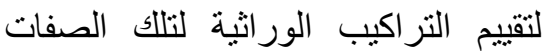
حيث يتوفر في ميعاد الزراعة العادي حرارة مناسبة وإضاءة شمسية كافية 
على المرتبة الأولى والثانية يليهما الفعل

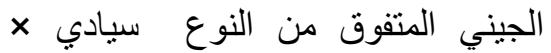
سيادي (1) في المرتبة الثالثة من حيث الثيث

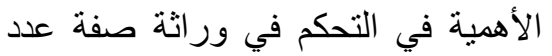

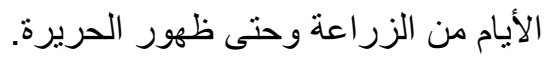

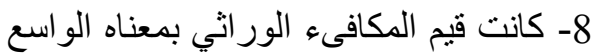

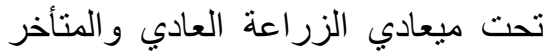

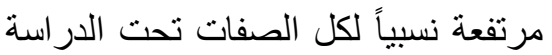

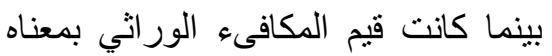
الدقيق مرتفعة أو منوسطة نسبياً لمكونات التئان

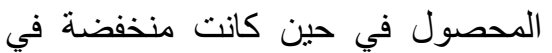

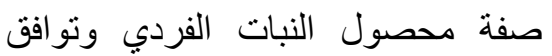
ذللك مع قيم التقدم الور اثي المتوقع و التي

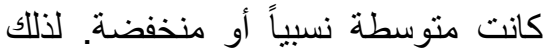
نستنتج أن الإنتخاب سيكون أكثر كفاءة

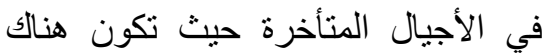
فرصة لحدوث أنعزالات متجات لكون هناوزة

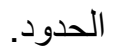

6- أظهرت الهجن الأربعة تحت الدراسة قيماً

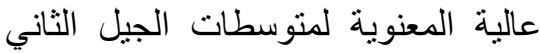
(m) F2

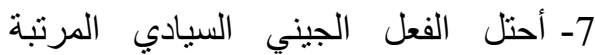
الأولى من حيث أهميته في التحكم في الهي وراثة كل الصفات تحت الدراسة عدا فئه

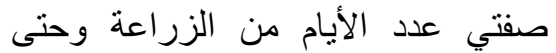

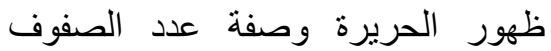
بالكوز، يليه في المرتبة الثانية أو الثالثة

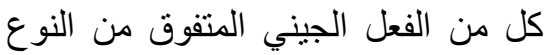

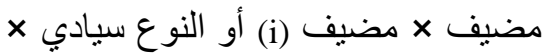

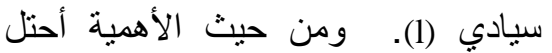

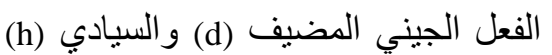
المرتبة الأولى والثانية في صفة ولكية عدد الفيادي الصفوف بالكوز بينما سبطر الألية في الفعل الجيني المتفوق من النوع مضيف لينكاف مضيف (i) والفعل الجيني المضيف (d) 